\title{
SPORTUOJANČIŲ IR NESPORTUOJANČIŲ PAAUGLIŲ SAVĘS VERTINIMO LYGIO IR PATYČIŲ SĄSAJA
}

\author{
Ilona Tilindienė, Irena Valantinienė, Dovilè Murauskaitė, Tomas Stupuris \\ Lietuvos kūno kultūros akademija, Kaunas, Lietuva
}

\begin{abstract}
Ilona Tilindienè. Socialinių mokslų (edukologijos) daktarè. Lietuvos kūno kultūros akademijos Socialinių ir humanitarinių mokslų katedros
\end{abstract} docentè. Mokslinių tyrimų kryptis — socialinė edukologija.

\section{SANTRAUKA}

Mokykloje kiekvienas vaikas turètujaustis svarbus ir saugus. Deja, realybė dažnai esti visai kitokia. Lietuvos ir užsienio mokslininkai teigia, kad mokyklose agresyvumo, tyčiojimosi mastas vis dideja ir, kaip írodyta empiriniais tyrimais (Andreou, 2001; Christian, Kashiwagi, 2007; Zaborskis, Vareikienè, 2008; Carlson, Cornell, 2008 ir kt.), yra vaiku. kurie nuolat patiria bendraamžiu patyčias mokykloje. Visgi tyrinètojai (Graziano, 2003; Haddock, 2006) tvirtina, kad bütu svarbiau išsiaiškinti, kokie individualūs pagrindiniai charakterio asmenybiniai ir socialinio pažinimo procesai susiję su patyčiu raiška, o ne analizuoti pati tyčiojimasi bei jo paplitimo masta, kuris ir taip ganètinai ištyrinètas. Daugelis sporto mokslininku (Boyd, Hrycaiko, 1997; Šniras, Malinauskas, 2006; Dunn et al., 2008 ir kt.) pripažista, kad isitraukimas i sportine veikla teigiamai veikia paaugliu savęs vertinima, prisideda prie paauglio tapatumo ir teigiamos savigarbos vystymosi, skatina bendradarbiavimq su bendraamžiais, ugdo fizinius gebejimus, charakteri, kūrybinguma, vertybiu sistema, atitraukia jị nuo žalingu ipročiu, padeda integruotis $i$ visuomenę.

Tyrimo tikslas — atskleisti sportuojančiu ir nesportuojančiu paaugliu savęs vertinimo lygio ir patyčiu sqsaja.

Tyrimo objektas — sportuojančiu ir nesportuojančiu paaugliu savęs vertinimo lygio ir patyčiu sasaja.

Apklausos metu, kuri buvo atliekama 2009 metais, tirti 386 Kauno ir Prienu miestu mokyklu 12 - 15 metu sportuojantys ir nesportuojantys paaugliai. Jiems buvo pateikta Shostrom savęs vertinimo metodikos (pakoreguota) anketa ir patyčiu anketa, parengta remiantis Didžiosios Britanijos Jorko miesto „Patyčiu klausimynu moksleiviams“.

Nustatyta, kad sportuojantys paaugliai patiria mažiau patyčiu nei nesportuojantys ju bendraamžiai (p <0,01). Tačiau lyties požiūriu statistiškai reikšmingas skirtumas tarp patiriamu patyčiu nustatytas tik tarp sportuojančiu ir nesportuojančiu vaikinu $(p<0,01)$ (pastarieji patyčias patiria dažniau). Didesné dalis paaugliu inicijuoja patyčias kartais, tačiau nei sportinès veiklos, nei lyties požiūriu statistiškai reikšmingo skirtumo tarp inicijuojamu paaugliu patyči nenustatyta $(p>0,05)$.

Tyrimas parodè, kad patiriantys patyčias paaugliai yra vidutinio ir žemo savęs vertinimo lygio. Tiriamieji, patys inicijuojantys patyčias, vidutiniškai vertina save, tačiau sportuojančiu vaikinu savęs vertinimo lygis yra aukštas. Statistiškai reikšmingas savęs vertinimo lygio skirtumas nustatytas tik tarp sportuojančiu ir nesportuojančiu vaikinu $(p<0,05)$

Analizuojant asmens patiriamu patyčiu ir jo paties tyčiojimosi iš kitu bendraamžiu ryš́ su savęs vertinimu, nustatyta silpna šiu reiškiniu priklausomybè nuo užsièmimo sportine veikla ir lyties.

Raktažodžiai: patyčios, savęs vertinimas, sportinè veikla.

\section{IVADAS}

$\mathrm{M}$ okykloje kiekvienas vaikas turètu jaustis svarbus ir saugus. Deja, realybė dažnai esti visai kitokia. Lietuvos ir užsienio mokslininkai nurodo, kad mokyklose agresyvumo, tyčiojimosi mastas vis dideja ir, kaip ịrodyta empiriniais tyrimais (Andreou, 2001; Christian, Kashiwagi, 2007; Zaborskis, Vareikienè, 2008; Carlson, Cornell, 2008 ir kt.), yra vaiku, kurie nuolat patiria bendraamžiu patyčias mokykloje.
Patyčias patiriančių ir iš kitų besityčiojančių moksleivių dažnis Lietuvos mokyklose yra didesnis negu kitose Europos šalyse. 2003 m. Lietuvoje atliktas tyrimas atskleide, kad bendraamžių tyčiojimąsi bent kartą yra patyrę apie 70\% moksleivių. Net $60 \%$ tirtų vaikų prisipažino, kad retkarčiais tyčiojasi iš savo bendraamžių (Povilaitis, Valiukevičiūtè, 2006). 2008 m. tyrimu taip pat irodyta, kad ne rečiau kaip 2-3 kartus per mènesi patyčias 
teko patirti daugiau kaip pusei $(52,3 \%$.) tirtu Lietuvos moksleiviu, kurie arba buvo kitu moksleiviu patyčiu aukomis $(18,3 \%)$, arba patys tyčiojosi is kitų moksleiviu (17,9\%), arba patyrè viena ir kita $(16,1 \%)$ (Zaborskis, Vareikienè, 2008).

Taigi pastaraisiais metais jaunų žmonių agresyvaus elgesio tyrimams skiriama itin daug dèmesio: analizuojama patyčių intensyvumas (O'Hanlon, 2006; Bullying by the numbers, 2007; Zaborskis, Vareikiene, 2008), formos (Povilaitis, Valiukevičiūte, 2006; Wilson, 2006; Teachers not trained to handle bullying, claims committe, 2007), lyčiu skirtumai (Wolfsberg, 2006; Cyberbullying, 2007; San Antonio, Salzfass, 2007), pasekmès asmenybès psichosocialinei sveikatai (Bullying by the numbers, 2007; Zaborskis, Vareikienè, 2008; Fleming, Jacobsen, 2009 ir kt.), ieškoma veiksmingu būdų ir priemonių, kaip spręsti šią problemą.

Visgi tyrëjai (Graziano, 2003; Haddock, 2006) tvirtina, kad būtu svarbiau išsiaiškinti, kokie individualūs pagrindiniai charakterio asmenybiniai ir socialinio pažinimo procesai sieja patyčių raišką, o ne pati tyčiojimąsi ir jo paplitimo masta, kuris ir taip ganėtinai ištyrinètas. Atliktų tyrimų (Andreou, 2001; Christie-Mizell, 2003) duomenys rodo, kad patyčių raiška labai susijusi su žmogaus savivoka, savęs vertinimu. Pavyzdžiui, vaikas, būdamas tyčiojimosi auka tarp bendraamžiu arba kęsdamas pažeminimą šeimoje, gali prasčiau save vertinti, vèliau ši negatyvų elgesi netgi kopijuoti. Tokie vaikai dažniau pradeda tyčiotis iš kitų, nes patys yra patyrę patyčias ir pažeminimą. Taigi labai dažnai agresiją mokiniai demonstruoja iš baimès ir nepasitikejjimo savimi, dèl to, kad negerbia savęs ir šitaip tikisi užsitarnauti pagarbą. Agresyvumas sumažina vidinę baimę, ir paaugliai naudojasi tuo norèdami save realizuoti ir padidinti savęs vertinimą (Prakapas, 2001). Merginų bejègiškumas ir kontragresija, vaikinų kontragresija yra veiksniai, verčiantys inicijuoti ar tęsti tyčiojimąsi (Jolliffe, Farrington, 2006). R. J. Hazler ir kt. (2006) teigi$\mathrm{mu}$, patyčių aukos taip pat yra prastesnių vidiniu asmens gebejjimų, dažnai yra izoliuotos socialiai, turinčios išryškintų asmeninių baimių, kaltinančios save dèl problemų ir apskritai žemos savivokos ir savęs vertinimo.

Paauglyste yra biologiniu, psichologinių ir socialiniu pokyčiu metas. Šiuo laikotarpiu intensyviai formuojasi savivoka, kurios vienas iš komponentu yra savęs vertinimas, parodantis individo požiūri i save ir priklausantis nuo savų gebejjimų, kompetencijos suvokimo. Paauglys, kuris save suvokia kaip gebantị daugelyje jam svarbių sričiu, yra linkęs adekvačiai save vertinti, sėkmingai socializuotis. Daugelis sporto mokslininku (Boyd, Hrycaiko, 1997; Šniras, Malinauskas, 2006; Dunn et al., 2008 ir kt.) pripažista, kad isitraukimas i sportinę veiklą teigiamai veikia paauglių savęs vertinimą, prisideda prie paauglio tapatumo ir teigiamos savigarbos vystymosi, skatina bendradarbiavimą su bendraamžiais, ugdo fizinius gebèjimus, charakteri, kūrybinguma, vertybių sistemą, atitraukia ji nuo žalingų ipročių, padeda integruotis $\mathfrak{i}$ visuomenę.

Deja, mokslinèje literatūroje pasigendama tyrimų, kurių metu būtų nagrinejjama sportavimo ir patyčių priklausomybė (pvz., koks gali būti sportavimo poveikis agresijos raiškai, patyčių prevencijai ir pan.), tuo labiau, kad mokslineje literatūroje nuolat diskutuojama, koks sporto poveikis asmenybès socialiniams igūdžiams, saviugdai, nuo kuriu priklauso individo elgesys aplinkoje (Šniras, Malinauskas, 2006; Šukys, Jankauskiene, 2008 ir kt.).

Šiuo tyrimu kẻlème prielaidą, kad paaugliai, kurių savęs vertinimo lygis yra aukštesnis, kurie patys save gerbia, turi atitinkamą socialinį statusą aplinkoje, neinicijuoja patyčių, patys jų nepatiria ir pozityviai socializuojasi.

Visa tai paskatino iškelti tyrimo tikslą - atskleisti sąsają tarp sportuojančiu ir nesportuojančių paauglių savęs vertinimo lygio ir patyčių.

Tyrimo objektas - sportuojančiu ir nesportuojančiu paauglių savęs vertinimo ir patyčių sąsaja.

\section{TYRIMO METODIKA}

Tiriamiesiems buvo pateikta Shostrom savęs vertinimo metodikos (pakoreguota) anketa, kurią sudare 26 teiginiai ir adaptuotas klausimynas, parengtas remiantis Didžiosios Britanijos Jorko miesto „Patyčių klausimynu moksleiviams“, kuri sudare 11 uždaro ir atviro tipo klausimu. Kiekvienas klausimas turejo nuo 2 iki 10 atsakymo variantų. Tiriamiesiems reikejjo pasirinkti vieną, kai kur kelis atsakymo variantus. Klausimyno adaptacijos procedūra aprašyta ankstesniuose straipsniuose (Tilindienè ir kt., 2010).

Tyrimo imtis ir organizavimas. Apklausa buvo vykdoma 2009 metais. Atsitiktinès patogiosios atrankos būdu atrinkti 386 sportuojantys ir nesportuojantys paaugliai $(12-15 \mathrm{~m}$.) (180 sportuojančiu ir 206 nesportuojantys paaugliai 198 merginos ir 188 vaikinai) iš Kauno ir Prienu miestų vidurinių ir sporto mokyklų, gavus šių mokyklų vadovų sutikimą. Anketos buvo pildomos prieš pamokas arba pratybas, paaugliams nebuvo leidžiama neštis anketų pildyti į namus. 
Sportuojančiais asmenimis laikème tuos, kurie mažiausiai po du kartus per savaitę lanko(-è) sporto pratybas sporto mokyklose ar klubuose ir sportuoja(-avo) ne mažiau kaip vienus metus ir dalyvauja(-avo) varžybose.

Statistinė analizè. Duomenys buvo analizuojami naudojantis statistinès duomenų analizès programiniu paketu SPSS for Windows 13.0. Kokybiniu požymių statistinis ryšys vertintas $\chi^{2}$ kriterijumi. Skirtumai laikyti statistiškai patikimais esant ne didesnei kaip 5\% paklaidai $(\mathrm{p}<0,05)$.

\section{REZULTATAI}

Analizuojant sportuojančių ir nesportuojančių paauglių atsakymus į klausimą, kaip dažnai iš jų buvo tyčiotasi, nustatyta, kad labai dažnai patiria patyčias $20 \%$ nesportuojančiu vaikinu ir $10,26 \%$ nesportuojančių merginų, kai tuo tarpu, labai dažnai patiriančių patyčias sportuojančiu paauglių buvo tik keletas procentų. Du trečdaliai nesportuojančių ir pusė sportuojančių merginų teigia, kad jos patiria patyčias kartais (taip nurodè ir $46,67 \%$ nesportuojančių bei 41,54\% sportuojančių vaikinu) (1 pav.).

Taigi, kaip ir tikètasi, statistiškai reikšmingai iš sportuojančiu paauglių yra tyčiojamasi mažiau nei iš nesportuojančiujų $\left(\chi^{2}(3)=18,95 ; p<0,01\right)$. Tačiau lyties požiūriu statistiškai reikšmingas skirtumas tarp patiriamų patyčių nustatytas tik tarp sportuojančių ir nesportuojančių vaikinų $\left(\chi^{2}(3)=\right.$ 16,$67 ; \mathrm{p}<0,01$ ) (pastarieji patyčias patiria dažniau), tarp sportuojančių ir nesportuojančių merginų patiriamų patyčių statistiškai reikšmingo ryšio nenustatyta $\left(\chi^{2}(3)=6,10 ; p>0,05\right)$.

Išryškejjo, kad kartais tyčiojasi iš kitu 70\% nesportuojančių vaikinų ir 51,28\% nesportuojančiu merginų bei apie pusè sportuojančiu vaikinų ir merginų. Didelè dalis tiriamujų pažymėjo, kad nesityčioja iš kitu ( 2 pav.). Statistinè analizè atskleidè: nei sportinès veiklos $\left(\chi^{2}(3)=6,47 ; p>0,05\right)$, nei lyties požiūriu statistiškai reikšmingo skirtumo tarp inicijuojamu paauglių patyčių nèra $\left(\chi^{2}(3)=\right.$ $5,68 ; p>0,05)$.

Duomenys rodo, kad patyčias patiriantys paaugliai yra vidutinio ir žemo savęs vertinimo — žemas savęs vertinimas būdingesnis ir nesportuojančioms, ir sportuojančioms merginoms. Aukšto savęs vertinimo lygio yra 22,02\% sportuojančių vaikinų. Visgi statistiškai reikšmingas skirtumas tarp patiriančiu patyčias paauglių savęs vertinimo lygio nenustatytas nei sportinès veiklos $\left(\chi^{2}(3)=7,24 ; p>0,05\right)$, nei lyties $\left({ }^{2}(3)=5,95 ; p>0,05\right)$ požiūriu ( 3 pav.).
1 pav. Sportuojančių ir nesportuojančių respondentų atsakymų i klausimą Kaip dažnai iš tavęs buvo tyčiojamasi mokykloje? procentinis skirstinys pagal lytị
2 pav. Sportuojančių ir nesportuojančių respondentų atsakymų i klausimą Kaip dažnai tu tyčiojiesi iš kitų mokykloje? procentinis skirstinys pagal lytị
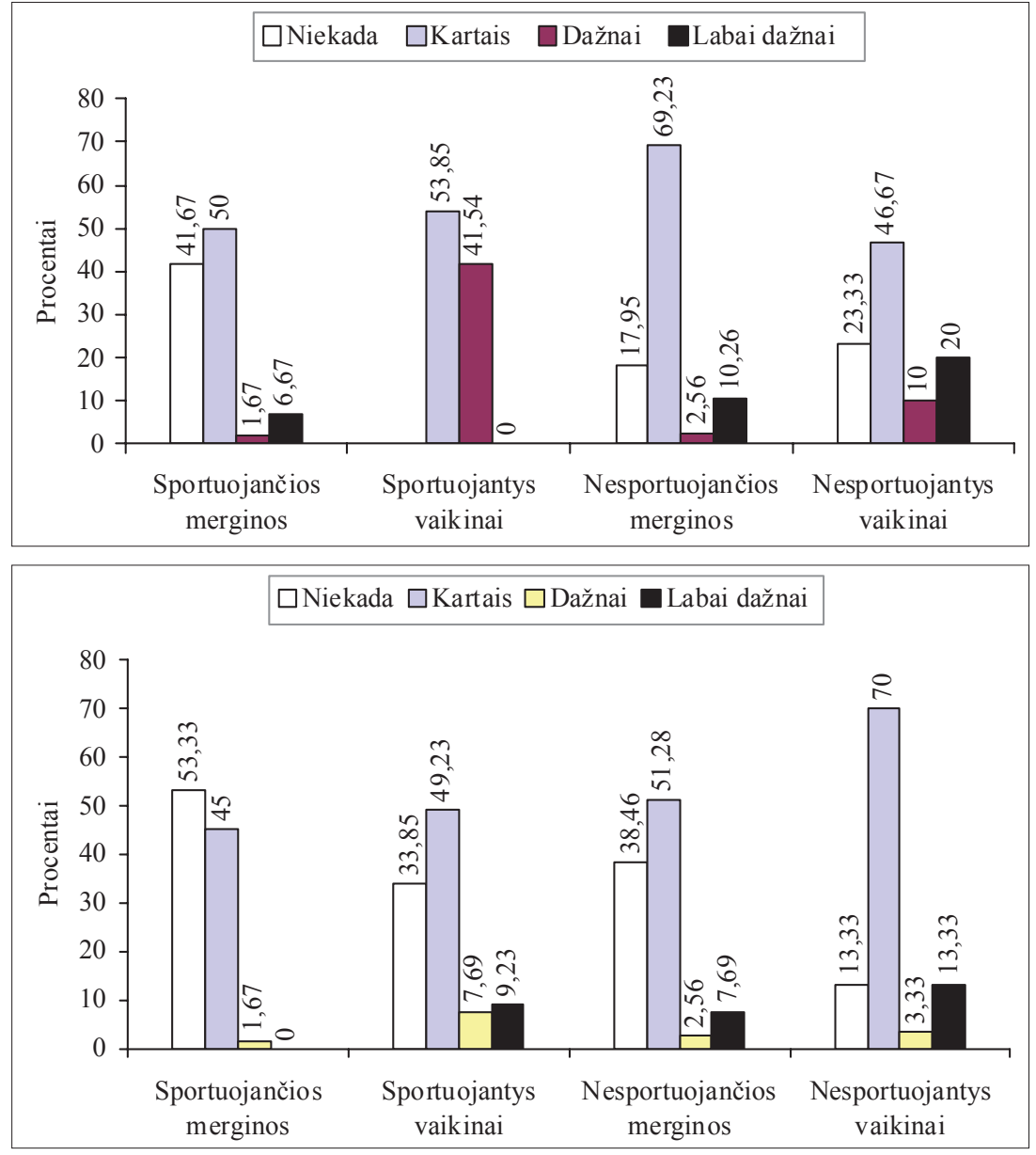

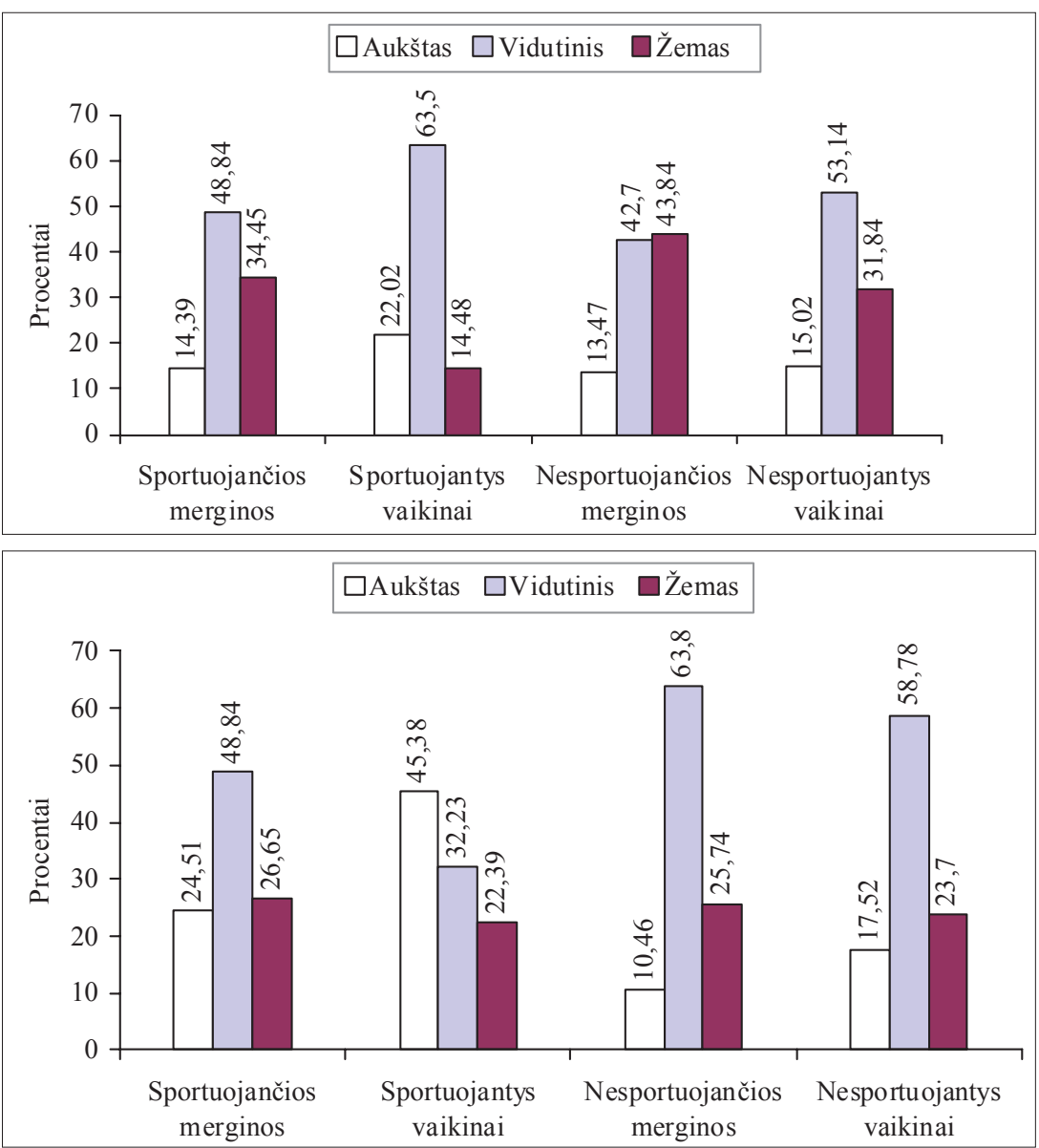

3 pav. Sportuojančių ir nesportuojančių paauglių, patiriančių patyčias, procentinis skirstinys pagal savęs vertinimo lygi
4 pav. Sportuojančių ir nesportuojančių paauglių, inicijuojančių patyčias, procentinis skirstinys pagal savęs vertinimo lygi
Tyrimo metu išsiaiškinus paauglius, kurie inicijuoja patyčias, nustatytas jų savęs vertinimo lygis. Vidutiniškai save vertina nesportuojantys paaugliai ir sportuojančios merginos, tuo tarpu sportuojantys vaikinai yra aukšto savęs vertinimo lygio (45,38\%). Taigi reikšmingas skirtumas tarp savęs vertinimo lygiu nustatytas tarp sportuojančių ir nesportuojančių vaikinų $\left(\chi^{2}(3)=10,64\right.$; $\mathrm{p}<0,05)$, tačiau lyties požiūriu šis skirtumas nereikšmingas $\left(\chi^{2}(3)=4,98 ; p>0,05\right)$.

\section{REZULTATUQ APTARIMAS}

Tyrimu nustatyta, kad tyčiojimasis yra paplitęs tarp 12-15 metu paaugliu. Tai patvirtina daugelio kitu autoriu (O`Hanlon, 2006; Wilson, 2006; McGuckin, Lewis, 2006; Bullying by the numbers, 2007; Zaborskis, Vareikiené, 2008) tyrimu duomenys, kad tyčiojimasis yra paplitęs, o jo mastas gan didelis. Iš sportuojančių paauglių yra tyčiojamasi mažiau nei iš nesportuojančių, sportuojantys paaugliai tyčiojasi mažiau nei nesportuojantys. Galima kelti prielaida, kad sportavimas teigiamai veikia ne tik fizinę, bet ir psichosocialinę vaiku raida. Pastarasis yra vienas iš reikšmingiausių veiksnių, prisidedančiu prie paauglių tapatumo, teigiamos savigarbos, charakterio ugdymo (Puniuškienè, Laskienè, 2006; Šniras ir kt., 2007). Teigiama, kad sportuojantys paaugliai labiau pasitiki savimi, ju populiarumas tarp bendraklasiu yra didesnis (Šertvytienė, Laskienè, 2008; Dunn et al., 2008), taigi pelnomas pripažinimas ittvirtina pagarbą tarp bendraamžių (Bump, 2000) ir aukštesnę socialinę integraciją (Šukys, Jankauskienè, 2008), todèl patyčių patiriama mažiau.

Tyrimo metu nenustatyta skirtumų tarp merginų ir vaikinų patiriamų ar inicijuojamų patyčių, kai tuo tarpu kitų mokslininkų tyrimų rezultatai atskleidžia lyties skirtumus, susijusius su agresyviu elgesiu. Nurodoma, kad berniukai agresyvesni ir dažniau priekabiauja nei mergaitès (San Antonio, Salzfass, 2007; Miller, 2007; Zaborskis, Vareikienè, 2008).

Paaugliai, inicijuojantys patyčias, yra vidutinio savęs vertinimo (sportuojantys vaikinai netgi aukšto), ir tai prieštarauja kitų tyrèju gautiems duomenims, atskleidžiantiems, kad labai dažnai agresija mokiniai demonstruoja iš baimès ir nepasitikèjimo savimi, dèl to, kad negerbia savęs ir šitaip tikisi užsitarnauti pagarba. Agresyvumas sumažina vidinę baimę, ir paaugliai naudojasi ja noredami save realizuoti ir šitaip padidinti savęs vertinimą (Pra- 
kapas, 2001; Christie-Mizell, 2003). Kita vertus, R. Ramanauskienès ir kitu (2004) atliktas tyrimas patvirtino, kad savęs vertinimas mažèja blogejjant santykiams su bendraamžiais.

Patyčias patiriantys paaugliai yra vidutinio savęs vertinimo lygio ir statistiškai reikšmingai nesiskiria nei pagal užsièmimą sportine veikla, nei pagal lytị, nei pagal savęs vertinimą. Tai nepatvirtina daugelio tyrimu, irodančių, kad paaugliai, kurie puikiai suvokia savo gebejjimus sporto srityje, geriau vertina ir save (Boyd, Hrycaiko, 1997; Bump, 2000), bet nesutampa su mokslininkų teigimui, kad patyčios yra prasto savęs vertinimo priežastis arba pasekmė (Christie-Mizell, 2003; Aluedse, 2006; McGuckin, Lewis, 2006; Fleming, Jacobsen, 2009).

Tyrimu nustatyta, kad paauglių savęs vertinimo lygmuo neturi sąsajų nei su patiriamomis, nei su inicijuojamomis patyčiomis, ir tai nesutampa su kitų tyrimų duomenims (Prakapas, 2001;
Christie-Mizell, 2003; Aluedse, 2006; McGuckin, Lewis, 2006; Fleming, Jacobsen, 2009 ir kt.). Apibendrinant galima kelti prielaidą, kad tyrimo imtis yra nepakankama, todèl būtina tęsti tyrimus didinant tiriamają imtị ir atsižvelgiant î paaugliu populiacija.

\section{IŠVADOS}

Sportuojantys paaugliai patiria mažiau patyčių nei nesportuojantys jų bendraamžiai, ypač tai išryškejjo tarp vaikinų. Patyčias patiriantys paaugliai yra vidutinio ir žemo savęs vertinimo lygio. Tiriamieji, patys inicijuojantys patyčias, taip pat vidutiniškai save vertina, tačiau sportuojančių vaikinu savęs vertinimo lygis yra aukštas. Analizuojant asmens patiriamu patyčių ir jo paties tyčiojimosi iš kitų bendraamžių sąsają su savęs vertinimu, priklausomybè tarp šių reiškinių nepastebèta.

\section{LITERATŪRA}

Aluedse, O. (2006). Bullying in schools: A form of child abuse in schools. Educational Research Quarterly, 30 (1), 37-49. Prieiga internetu: http://search.epnet.com/ custlogin.asp? custid $=\mathrm{s} 5018438$.

Andreou, E. (2001). Bully / Victim Problems and their Association with Coping Behaviour in Conflictual Peer Interactions Among School-age Children. Educational Psychology, 21(1), 59-66. Prieiga internetu: http://search. epnet.com/custlogin.asp?custid=s5018438.

Boyd, K. R., Hrycaiko, D. W. (1997). The effect of a physical activity intervention package on the self-esteem of pre-adolescent and adolescent females. Journal of Adolescence, 32 (127), 131-139.

Bullying by the numbers. (2007). Curriculum Review, 01472453, 46 (5). Prieiga internetu: http://search.epnet. com/custlogin.asp?custid=s5018438.

Bump, A. (2000). Sporto psichologija treneriui: studiju vadovas. Vilnius: Lietuvos sporto informacijos centras.

Carlson, L. W., Cornell, D. G. (2008). Differences between persistent and desistent middle school bullies. School Psychology International, 29 (4), 442-45. Prieiga internetu: http://psr.sagepub.com/cgi/content/abstract/.

Christian, C., Kashiwagi, A. (2007). The wrong plan for schools? Newsweek (Atlantic Edition), 01637053, 1 / 15 149 (3). Prieiga internetu: http://search.epnet.com/custlogin.asp?custid $=$ s5018438.

Christie-Mizell C.A. (2003). Bullying: The consequences of interparental discord and child's self-concept. Family Process, 42 (2), 237-251.

Cyberbullying. (2007). State legislature, 33 (6), 13. Prieiga internetu: http://search.epnet.com/custlogin. asp? custid $=\mathrm{s} 5018438$.

Dunn, C., J., Dunn, J. G. H., Bayduza, A. (2008). Perceived athletic competence, sociometric status, and loneliness in elementary school children. Journal of Sport Behavior, 30 (3), 249-269. Prieiga internetu: http://search.epnet. com/custlogin.asp?custid=s5018438.

Fleming, L. C. Jacobsen K. H. (2009). Bullying and symptoms of depression in Chilean middle school students. Journal of School Health, 79 (3), 130-137. Prieiga internetu: http://web.ebscohost.com/ehost/ pdf? vid $=19 \&$ hid $=2 \&$ sid $=6$ fc $2 d 4 d 0-092 d-4 b 77-84 d 8-$ 84743b156b3f\%40sessionmgr8

Graziano, W. G. (2003). Personality development: An introduction toward process approaches to long-term stability and change in persons. Journal of Personality, 71 (6), 893-903. Prieiga internetu: http://search.epnet.com/ custlogin.asp? custid $=\mathrm{s} 5018438$.

Gudžinskienė, V., Laucevičienè, J. (2001). Paauglių emocinè savijauta ir požiūris ị santykius su tèvais. Pedagogika, $53,40-45$.

Haddock, G. (2006). Do I get better looking each day? Changes in self-perceptions of attractiveness as a function of temporal perspective. European Journal of Social Psychology, 36 (5), 761 - 771. Prieiga internetu: http://search. epnet.com/custlogin.asp?custid=s5018438.

Hazler, R. J, Carney, J. L., V., Granger, D. A. (2006). Integrating biological measures into the study of bullying. Journal Of Counseling \& Developmen, 84, 298307. Prieiga internetu: http://search.epnet.com/custlogin. asp? custid $=\mathrm{s} 5018438$.

Jolliffe, D., Farrington, D. P. (2006). Examining the relationship between low empathy and bullying. Aggressive Behavior, 32 (6), 540-550. Prieiga internetu: http:// search.epnet.com/custlogin.asp?custid $=\mathrm{s} 5018438$.

McGuckin, C., Lewis, C. A. (2006). Experiences of school bullying in Northern Ireland: Data from the life and times survey. Adolescence, 41 (162), 313-320. Prieiga internetu: http://search.epnet.com/custlogin.asp?custid=s5018438.

Miller, K.E. (2007). Psychopathologic behavior: A consequence of bullying? American Family Physician, 1 / 15, 75 (2), 252-257. Prieiga internetu: http://search.epnet. com/custlogin.asp?custid $=\mathrm{s} 5018438$.

O'Hanlon, L. H. (2006). Hostile halls. Current Health, 33 (2), 16-18. Prieiga internetu: http://search.epnet.com/ custlogin.asp? custid $=$ s5018438. 
Patyčiu klausimynas moksleiviams. (2008). Prieiga internetu: (http://www.state.de.us/attgen/main_page/teachers/ bullquesti.htm)

Povilaitis, R., Valiukevičiūtè, J. (2006). Patyčiu prevencija mokyklose. Vilnius: Multiplex.

Prakapas, R. (2001). Paaugliu tarpusavio agresija mokykloje. Pedagogika, 53, 113-115.

Puniuškienė, R., Laskienė, S. (2006). Sportuojančiu paauglių vertybinių orientacijų, asmenybès savybių ir savigarbos ypatumai. Sporto mokslas, 4 (46), 48-54.

Ramanauskienè, R., Valantinas, A., Endriulaitytè, A. (2004). Paauglių savęs vertinimo bei santykių su bendraamžiais ir tèvais sąveikos ypatumai. Pedagogika, 71, 91-96.

San Antonio D. M., Salzfass, E. A. (2007). How we treat one another in school. Educational Leadership, 64 (8), 32-38. Prieiga internetu: http://search.epnet.com/custlogin.asp? custid $=$ s5018438.

Šertvytienè, D., Laskienè, S. (2008). Sportuojančiu paaugliu vertybinès orientacijos kaip socialinès kompetencijos veiksnys. Ugdymas. Küno kultūra. Sportas, 4 (71), $104-110$.

Šniras, ك̌., Dumčienè, A., Dumbliauskas, A. (2007). Sportuojančių ir nesportuojančiu mokinių socialinių igūdžių ypatumai. Pedagogika, 85, 110-115.
Šniras, Š., Malinauskas, R. (2006). Miestų ir rajonų krepšinio sporto mokyklų moksleivių socialinių igūdžių raiška. Ugdymas. Kūno kultūra. Sportas, 4 (63), 111-117.

Šukys, S. Jankauskienė, R. (2008). Mokinių sportavimo ir fizinio aktyvumo laisvalaikiu sąsajos su psichosocialiniais, elgesio ir mokyklos veiksniais. Ugdymas. Küno kultūra. Sportas, 1 (68), 92-99.

Teachers not trained to handle bullying, claims committe. (2007). Education, 3 (30), 1263-1268. Prieiga internetu: http://search.epnet.com/custlogin.asp? custid=s5018438.

Tilindienè, I., Rastauskienè, G. I., Valantienè, I., Lagūnavičienè, N. (2010). Sportuojančių ir rizikos grupès paauglių patiriamų ir jų pačių vykdomų patyčių dažnumas. $U g d y$ mas. Kūno kultūra. Sportas, 1 (76), 101-108.

Wilson, A. (2006). The bully problems. World \& I, 21 (8), 8 -12. Prieiga internetu: http://search.epnet.com/custlogin. asp? custid $=\mathrm{s} 5018438$.

Wolfsberg, J. S. (2006). Student safety from cyberbullies, in chat rooms, and in instant messaging. Education digest, 72 (2), 33-37. Prieiga internetu: http://search.epnet.com/ custlogin.asp?custid=s5018438.

Zaborskis, A., Vareikienė, I. (2008). Patyčios mokykloje ir jų sąsajos su moksleivių sveikata bei gyvensena. Medicina, 44 (3), 232-239.

\title{
RELATION BETWEEN ATHLETES AND NON ATHLETES ADOLESCENTS' SELF-ESTIMATION LEVEL AND BULLYING
}

\author{
Ilona Tilindienė, Irena Valantinienė, Dovilė Murauskaitė, Tomas Stupuris \\ Lithuanian Academy of Physical Education, Kaunas, Lithuania
}

\begin{abstract}
In school every child has to feel important and safe. But the reality is absolutely different. Lithuanian and foreign scientists indicate that in schools the scale of aggresiveness and bullying increases and, as proved by empirical research (Andreou, 2001; DeRosier, 2004; Palujanskienė, Uzdila, 2004; Povilaitis, Valiukevičiūtè, 2004; Christian, Kashiwagi, 2007; Carlson, Cornell, 2008; Zaborskis, Vareikienè, 2008 and others), there are children who constantly experience bullying by coevals at school. However, researchers (Graziano, 2003; Haddock, 2006) maintain that it would be more important to know what individual and social cognitive processes are linked bullying resolution, rather than phenomenon bullying which has already been sufficiently studied.

Aim of the research was to disclose the relation between athletes and non-athletes adolescents self-esteem level and bullying.

Research object was the relation between the athletes and non-athletes adolescents' self-esteem level and bullying.

In the interview, respondents were 386 (12-15 year) adolescents (athletes and non-athletes) from Kaunas and Prienai secondary and sport schools. The questionnaire was prepared on the basis of Bullyings Questionnaire for Schoolboys / girls (2008), and Shostroms' method of self-esteem.

Results. We found that athletes adolescents suffered less bullying than non-athletes $(p<0.01)$. However, their gender produced statistically significant differences between experienced bullying: we established them only between athlete and non-athlete boys $(\mathrm{p}<0,01)$ (the latter suffered from bullying more often).

The study showed that experienced bullying by adolescents was linked to medium and low self-assesment. The subjects who initiated bullying themselves, also had an average level of self-assesment, but athlete boys' self-esteem was high. Statistically significant self-assesment differences were only between athlete and nonathlete boys $(\mathrm{p}<0.05)$.
\end{abstract}

Keywords: bullying, self-esteem, sports activities.

Gauta $2010 \mathrm{~m}$. kovo $15 \mathrm{~d}$.

Received on March 15, 2010

Priimta 2010 m. gegužès $31 \mathrm{~d}$

Accepted on May 31, 2010
Ilona Tilindienè

Lietuvos kūno kultūros akademija

(Lithuanian Academy of Physical Education)

Sporto g. 6, LT-44221 Kaunas

Lietuva (Lithuania)

$\mathrm{Tel}+37037209050$

E-mail i.tilindiene@1kka.lt 